\title{
Introduction: The Culture of Conflict in Israel and Palestine
}

\author{
Uri Ram • Jeffrey C. Goldfarb
}

Published online: 21 March 2009

(C) Springer Science + Business Media, LLC 2009

A cliché would have it that the struggle between Israel and Palestine is as long as the history of these two communities; but reality is that the history of this conflict preceded the existence of these communities and, more importantly, it is the conflict itself that had constructed and shaped the identities of these two warring communities. If one marks the beginning of modern Zionist settlement in Palestine in 1881 as the starting point of the conflict, then one "celebrates" this year 128 years of conflict, one that started long before there was the state of Israel, or even a Jewish community in Palestine to speak of, and before there was a Palestinian nation there to speak of. Israeli and Palestinian nationalism are the two modern national identities that emerged out of the encounter between settlers and indigenous people in the territory of Palestine, and they carry little resemblance, if at all, to their old communities of ancestry - the Jews in the Diaspora locations and the Arabs in Palestine under the Ottoman Empire. This critical narrative differs substantially from the narratives that the national protagonists tell themselves and others-about the "perennial" origins in the land and about their historical "right" to it.

But while the conflict and its periodical eruptions in hostilities and bloodshed captures the attention of world communication and public opinion, the ways in which the two sides to the conflict design their culture through their mutual relations is much less discussed and understood. It is to this aspect - the culture of the conflict - that this issue is devoted. Part of the articles in it emerged out of a workshop on "Israel and Palestine" that was held in 2006 at the New School for Social Research, and was coordinated by the guest editors of this issue, Uri Ram of Ben-Gurion University and Jeffrey C. Goldfarb of the New School. Other articles were added later. Together they offer a mix of variety of topics and perspectives on the common theme of the culture of the conflict in Israel and Palestine. They share not only a common theme but also an implicit focus: all the articles relate to

\footnotetext{
U. Ram $(\bowtie)$

Ben-Gurion University of the Negev, Be'er Sheva, Israel e-mail: uriram@bgu.ac.il

J. C. Goldfarb

Department of Sociology, New School for Social Research, 65 Fifth Avenue, New York, NY 10003, USA

e-mail: goldfarj@newschool.edu
} 
everyday culture and to common people, or to what Goldfarb has termed elsewhere as "the politics of small things", i.e., the way in which the conflict shapes ordinary lives, and the ways in which ordinary lives in turn affect the conflict. Furthermore, all the articles emphasize the ways in which culture is not only anchored in the national binarity, but also in a jigsaw of crisscrossing internal schisms and non-hegemonic groups in each of the national entities: Arab women in mixed cities, Palestinian poets, Palestinian migrant workers, Islamic thinkers, Jewish bereaved families, Israeli soldiers, and others. The multiplicity of cases, voices and perspectives offered here is but a vignette to the questions of the culture of conflict that is yet calling for research and analysis.

Hanna Herzog maintains that choices of Arab women in mixed cities offer an alternative sociopolitical order based on a conscious, intentional choice. The choice to live in a mixed city and everyday life in this city constitutes an alternative life space for these women. This allows them to express their opposition to both their own minority community and the larger Jewish society, which at the same time serves as a setting for social change.

Honaida Ghanim analyzes the poetry of the Palestinian Nakba-the disaster of 1948. She argues that this poetry was intentionally simple, direct, and easily memorized, so that it could have become the ultimate cultural channel to create and disseminate the Palestinian experience of the 1948 war and its consequences and offer a future vision. This poetry became the reference point for Palestinians' national ethos and myths. Nevertheless she also points out that the poetry was explicitly masculine and was unable to transgress the patriarchic rural form of life that was hegemonic in Palestinian society.

Meirav Aharon Gutman argues that too much attention is given in the common discourse to state policies and diplomatic tactics "from above" and too little attention is given to the reality that is created "from below". She inquires what the "peace process" meant to migrant Palestinian workers in Israel. Through an ethnographic study she challenges accepted theories of borders and borderland in the case of Israel and Palestine and asks what can be learned about the cultural identity of people from the ways they cross, understand and move between geopolitical and cultural boundaries.

Issam Aburaiya addresses the issue of Islamic politics and tackles the assumed "clash of civilizations" between "Islam" and the "West". He argues that it is not Islamic movements and ideology in themselves that generate this schism, but that it is rather an effect of their incorporation into the scheme of Western modernity, with its binary distinctions and evolutionary reading of history. Using examples from Iran and Palestine, he shows how Islamic ideology indeed defies the basic premises of Western discourse on modernity, exposes its limitations, and yet questions the constitution of Islam and the West as allegedly distinct, even opposing, categories.

Yagil Levy addresses the attitudes in Israeli society to the sacrifice of life in war. $\mathrm{He}$ registers a change over time that is reflected in the bereavement discourse. Attitudes have shifted from the unquestioned justification of military losses to the emergence of an antiwar bereavement discourse, and later to a discourse that accepts losses. He argues that the social composition of military conscripts affects the level of sensitivity to losses. While secular upper-middle class groups tend to show a high level of sensitivity to war losses, which they then translate into a subversive bereavement discourse, religious and peripheral groups with a hawkish agenda are more tolerant of military losses, or, alternatively, may seek to avoid excessive casualties by improving the military's performance or the quality of the political directives.

Nir Gazit investigates state power beyond the limits of its official boundaries, by examining how "intruder states" produce, manage and sustain effective authority over occupied territories and populations. He uses the case of the Israeli occupation in the West 
Bank to demonstrate how political authority is based on "fragmented sovereignty", which is comprised of multiple, localized and relatively autonomous cores of power, instead of an all-encompassing structural and centralized modality of control. Fragmented sovereignty is shaped and operated through the autonomous power of ground level state agents, and in the ways spatial perceptions and practices are interwoven into localized political processes.

Lev Grinberg deals with the power of words, or rather the powerlessness of speechlessness. He argues that none of the common words used to describe or analyze the Israeli-Palestinian situation is adequate. Words such as "democracy" in reference to Israel, or "occupation" with reference to Israeli rule over the occupied territories, are far from capturing the intricacies and complexities of the situations in their particular context and history, and, furthermore, such words hinder political agency. "Things without a name" are hard to fight with. Grinberg thus is calling for a politics of naming in order to facilitate emancipatory agency.

The editors of IJPCS and the guest editors of this issue gladly provide these articles, hoping that they help shape discussion about a major area of conflict in our world. There are no easy solutions to complex problems, but the authors of the special issue suggest that one must look very closely to realize what the problems are. War, peace, and autonomy in Israel Palestine are about details, such as the ones illuminated in this issue. 